\title{
INDONESIAN ISLAMIC EDUCATION: Towards Science Development
}

\author{
Handoko Ja'far \\ STAI Ma'had Aly al-Hikam, Malang \\ e-mail: hokohan@yahoo.co.id
}

\begin{abstract}
Education as the root of civilization has an important role in preparing human resources toward the effort of developing sciences. Nowadays, Moslem in the world are are divided into two attitudes: resisting and refusing the development of sciences. Both of the attitutes are needed to bridge wisely. It meant no one is burdened in facing modern sciences by the ways of appreciating the modern sciences, applying them appropriately and learning from the history of the development of knowledge in the glory age of Islam. This article tried to confirm that science as a result of education, is not only the representation of civilization but also the demonstration of the high value of civilization. In Indonesia, the idea to reconstruct the model of Islamic education is getting stronger in accordance with the development of modern education. In this context, the clasical knowledge as heritance needed to be transformed into the modern one. Transformation is something unavoidable by the institutions of Islamic education.
\end{abstract}

Pendidikan -sebagai akar peradaban- memiliki peran penting dalam menyiapkan sumber daya manusia menghadapi perkembangan ilmu. Saat ini, sikap umat Islam terbelah menjadi dua: menolak dan menerima perkembangan ilmu. Kedua sikap ini perlu ditengahi secara bijaksana. Caranya, merasa tidak terbebani dalam menghadapi sains modern dengan memberikan apresiasi dan menerapkannya secara benar. Di samping itu, dengan cara belajar dari sejarah perkembangan ilmu di masa kejayaan Islam. Artikel ini berusaha menegaskan bahwa ilmu pengetahuan sebagai buah dari pendidikan, tidak hanya menjadi representasi peradaban tetapi juga mampu menunjukkan tingginya nilai peradaban. Di Indonesia, gagasan untuk merekonstruksi model pendidikan Islam menguat seiring dengan perkembangan pendidikan modern. Dengan demikian, meskipun pengetahuan klasik merupakan warisan, namun perlu dilakukan transformasi ilmu yang selaras dengan dunia modern. Perubahan merupakan hal yang tidak dapat dihindari oleh lembaga pendidikan Islam.

Keywords: Islamic education, development of knowledge, Islamic institution, transformation of science 


\section{A. Preface}

The conscious effort in maturing the human kind has been taken over its function by educational institutions. Concerned with a fanatic in faith toward religion, education will tighten in specification of certain religious educational institution. In this case, madrasah, pesantren, and college which are identical with Islamic group become a flavor place where parents put their trust in educating their children.

In short, Islamic education that is often meant as a conscious effort in socializing and applying the normative teachings and internalizing its values still have a place within adherents' heart. Take into account, many inventories done by the predecessors were positive contributions in the field of sciences in golden era of Islam. It means that the civilization that is well-marked with the existence of continuous advancement, recently it seems like a shift from West to East.

Yet, modern science advancement and technology have the impact of two different things. Both are considered as a trigger of moral decadency in the community of Moslems. The other side, science and technology become not only a new mode as a reference of information of knowledge that can not be dammed anymore but also as a device of education that is supposed to own.

Looking back the Islamic education in Indonesian and viewing memory of the development of science in the history of Islam is writer's effort in taking the benefit of history facts with its values. The choice of historic-sociologic study here is expected to become a model of Indonesian Islamic education in order to step forward as an educational institution that does not deny the development, progress and advancement and not go out of fashion. The collateral progress that is in step with today's demands to be better life. An education that is not only able to utilize the inventories but also strive for its development just like what all predecessors already done before.

\section{B. Islamic Education on Indonesian Historical Stage}

Syed Sajjad Husain and Syed Ali Ashraf in the book Crisis in Moslem Education asserted that Islamic education is a program which trains the sensibility of pupils in such a manner of attitude to life, action, decisions and approach to all kinds of knowledge. It aims at building the Moslem personality, 
who has religious sensitivity, social solidarity and scientific methodology. And socially, according to M. al-Afendi, Islamic education aims at:

"Building a society of good, pious and God-fearing in individuals, where social justice prevail, where toleration, brotherhood, love mercy, goodness and righteousness are predominant, based on mutual consultation of individual's intellectual capacities, where individuals enjoy freedom of thought and are competent to take responsibility, where individuals can live an ideal, pure and happy life."1

One thing supposed to say is a strong relationship between Islamic education and Islamic civilization which cannot be separated each other. And both demand to be built at the same time. In other word, Islamic education is to build Islamic culture and Islamic civilization at once. Islamic culture is reflected in the art, ethic, aesthetic, and a religious value (aqidah, syariah, akhlaq) that is internalized into individuals, and Islamic civilization is reflected in the social system, politic, economy, and technology included.

Today's Islam existence in Indonesian archipelago historically must be the result of long struggle of Islamic education. An historical study on the role of Islam and Islamic education in developing Indonesian community had done by Azyumardi Azra and Syed Muhammad Naquib al-Attas as stated in their books; Jaringan Ulama Timur Tengah dan Kepulauan Nusantara Abad XVII dan XVIII and Islam dan Kebudayaan Melayu. ${ }^{2}$

Zuhairini in the book Sejarah Pendidikan Islam stated that Islamic education along the history of this country could be written briefly as below; In the period of Dutch colonialism, it was no place for Islamic educational program in the governmental schools. They were stated as the religion free institution. ${ }^{3}$ And the colonial government did never acknowledge the existence of the religious school of Moslem community. Therefore, the graduates of this educational institution were considered as illiterates. ${ }^{4}$

In the Japan colonialism period, ulama were free to teach the religious knowledge in their schools (madrasah and pesantren) without any pressure from the colonial government. Even, some well-known pesantren were visited

\footnotetext{
1al-Fendi, M.H., "Toward Islamic Curricula”, in M.H. al-Fendi \& N.A. Baloch (eds.), Curriculum and Teacher Education, (Jedah: King Abdul Aziz University/London: Hodder and Stounghton., 1980).

${ }^{2}$ Abu Darda', "Islamic Education for the Future," involved in Journal At-Ta'dib, Gontor, 2005, p. 43-44.

${ }^{3}$ Zuhairini, Sejarah Pendidikan Islam, (Jakarta: Ditbinperta, 1986), p. 149.

4Zuhairini, Sejarah Pendidikan Islam, p. 147.
} 
by them. But, Islamic education world generally were nearly paralyzed because of romusha and other colonial activities. ${ }^{5}$

When this country got its independence, it inherited the dichotomy of education, i.e. public school and religious school, also governmental school and private one. So that, the program of Islamic education must be accommodated in the curriculum of public school to minimize this dichotomy. In the year 1951 the subject matter of Islamic was taught for pupils of class IV (Public Elementary School). And Junior High School and Senior High School, the subject matter of Islamic education was taught in 2 periods ( $2 \times 45$ minutes) per-a week. ${ }^{6}$

To minimize the dichotomy of education, in the year 1976 the government; the department of education and culture, department of religious affair, and department of interior regulated the equalization of public and religious school's certificate. ${ }^{7}$ In the Journal at-Ta'dib, "Desentralisasi Pendidikan dan Otonomi Daerah" Azyumardi Azra confirmed that Public school is institution of education under the regulation of department of education and culture and religious school is under the regulation of the department of religious affair. Nowadays there is an idea to make one roof policy for both public and religious education institutions. This idea is shown in the changing the department of education and culture becomes The Department of National Education. In other side, the regulation of decentralization or district autonomy in the field of politic and economy is not impossible influencing the field of education. ${ }^{8}$

The historical traveling of both public and religious schools in this country showed us an inter-approaching tendency. The study of Karel A. Stenbrink, Pesantren, Madrasah dan Sekolah: Pendidikan Islam dalam Kurun Modern and Mastuhu in his book Dinamika Sistem Pendidikan Pesantren: Suatu Kajian tentang Unsur dan Nilai Sistem Pendidikan Pesantren found that many pesantren and madrasah began appreciated toward general (natural and social) sciences. Meanwhile, public schools appreciated the religious educational activity such as pesantren kilat, especially along school holidays. And A. Malik Fajar in the book Membangun Madrasah sebagai Wahana Peradaban Modern concluded that

\footnotetext{
5 Zuhairini, Sejarah Pendidikan Islam, p. 151.

${ }^{6}$ Zuhairini, Sejarah Pendidikan Islam, p. 153.

7 Zuhairini, Sejarah Pendidikan Islam, p. 239.

${ }^{8}$ Azyumardi Azra, "Desentralisasi Pendidikan dan Otonomi Daerah", involved in Journal at-Ta'dib. Vol. 2, No. 1, 2015, p. 45.
} 
policies of government in the field of education developed and appreciated toward the programs of Islamic education in public school. ${ }^{9}$

One important note took by Abu Darda'10 as stated in his article "Islamic Education for the Future" is that the struggle of Islamic education in Indonesia is still going on perfect yet. The various challenges are still on the road to industrial Islamic civilization. With no rejecting that point of view above, seeing again the historical traveling: past and present, factually Islamic education in Indonesia is still far away from perfection and it will never be perfect because of distortion behind the consciousness in developing the education in which fund rising problems get involved as a classic reason and of course including an unwillingness to be professional. It is like what Agus Maimun ${ }^{11}$ found in his Research and Education Development that is misconception on the purpose of the making of education. From where education is started and to where it deserves to end.

\section{Science Development in the History of Islam}

Marshall G.S Hodgson in the book The Venture of Islam stated that science development in the world of Islam can not be separated from the history of Islam expansion. The expansion of magnificence (dakwah) in history of Islam called as opening the country (futūh al-buldān) went on rapidly and persisted with no dammed up. About 25 years after the death of the prophet Muhammad SAW (632 AD), Moslems had conquered all over Arabian Peninsula, from south to north. And it is not up to one century (750 AD) territory of Islam covered almost all Alexander's colonial in Asia (Caucasus) and North Africa (Libya, Tunisia, Aljazzier, and Morocco), covered Mesopotamia (Iraq), Syria, Palestine, Persia (Iran), Egypt plus Liberia Peninsula (Spanish and Portuguese) and India. ${ }^{12}$

Consequence of Islamic expansion is about tradition and culture integration and internalization of local civilization which elements and local society values accepted and filtered. Seyyed Hossein Nasr in his speech, Islam and Modern Science said, "In both cases, there was a period of transmission but there was

\footnotetext{
${ }^{9}$ Abu Darda', "Islamic Education for the Future”, Journal At-Ta'dib, 2005, p. 45.

${ }^{10} \mathrm{An}$ Islamic Education lecturer of Universitas Darusalam Gontor.

${ }^{11}$ Graduate program lecturer at State Islamic University of Malang.

${ }^{12}$ Syamsuddin Arif, “Sains di Dunia Islam: Telaah Historis-Sosiologis," Jurnal Islamia, 2005, p. 87.
} 
also a period of digestion, ingestion, and integration, which always means also rejection. No science has ever been integrated any civilization without some of it also being rejected. It's like the body, if we only ate and the body did not reject anything we would die in a few days. Some of the food has to be absorbed; some of the food has to be rejected".13

The translation of the scientific works from Greek and Syriac into Arabic in the era of Bani Umayyah governance centered in Damascus, Syria became an effort to study and understand the intellectual tradition of the country where conquered. After $750 \mathrm{AD}$ acceleration happened to follow as Abbasiyah Emporium established in Baghdad. ${ }^{14}$

The scholars, paderi and local educated people were recruited as staff in the government. In their hands, the development of thought were colored, such as Ibn al-Muqaffa' (759 AD), and Yahya Ibn khalid Ibn Barmak (803 AD). Ibn alNadm in kitab al-Fihrist and Dimitri Gutas in his book Greek Thought in Arabic Culture: The Greek -Arabic Movement in Baghdad and Early Abasid Society (2nd$4^{\text {th }} / 8^{\text {th }}-10^{\text {th }} C$ ) said that translation project intensively and massively done in the era of khalifah al-Ma'mun (833 AD). It was indicated with the library Bayt alHikmah built and became center of study. Many researchers and translators such as Hunayn Ibn Ishaq and his son Ishaq Ibn Hunayn, Abu Bishr, Matta Ibn yunus, Yahya Ibn Adi contributed in translating all Greek scientific corpus which included several knowledge, medical, math, astronomy, physic, philosophy, astrology, and even alchemy. ${ }^{15}$

According to the expert of sociology, Abdel Hamid Sabra, translation movement represents the first phase of three phases of science islamization. He said that translation is acquisition phase in which Greek science got Islamic civilization not as an invading force but as an invited guest. And it was still an effort to be careful and not to close. The next was acceptation phase or adoption which Moslems took and enjoyed the gift of Greek. The result of this phase was the birth of Jabir ibn Hasym (815 AD), al-Kindi (873 AD) and Abu Mashar (886 AD). ${ }^{16}$

\footnotetext{
${ }^{13}$ http://web.mit.edu/mitm-sa/www/NewSite/libstuff/nasr/nasrspeech1.html, accessed on September 12th, 2015.

${ }^{14}$ Syamsuddin Arif, "Sains di Dunia Islam: Telaah Historis-Sosiologis," p. 88.

${ }^{15}$ Syamsuddin Arif, "Sains di Dunia Islam: Telaah Historis-Sosiologis," p. 88.

${ }^{16}$ Syamsuddin Arif, “Sains di Dunia Islam: Telaah Historis-Sosiologis,” p. 88.
} 
The process of knowledge adoption stepped ahead to the next phase is assimilation or naturalization that Moslems not only accepted and enjoyed but also started to gather and created to spread as it is detailed in the encyclopedia of History of Arabic Science, ed, Roshdi Roshed, many scientists here are alKhawaritz (863 AD) and Ibn al-Nafis (1288 AD) in field of medical and Ibn alHaythan (1048M) and al-Idrisi (1150 AD) in geography and many more. ${ }^{17}$

The phase of overripe continues around 500 years. Its indicators are the high productivity and incredibly originality such as al-Battani (929 AD) corrected and revised astronomy system belongs to Ptolemy. Willy Hartner in his article Dictionary of Scientific Biography stated that al-Battani's works translated into latin, that is De Scientia Stellarum used as a reference by Kepler and Copernicus. A critic on Ptolemy's theories were also done by Ibn Rushd (1198 AD) and al-Bitruji (1190 AD). It was started in The Andalusian revolt against Ptolemaic Astronomy: Averroes and al-Bitruji by al-Sabra. Meanwhile in the field of Physic, Ibn Bajjah (1138 AD) anticipated Galileo with his critics on Aristhoteles's theory about movement power and speed (Journal of History of Ideas, Earnest A. Mordy) also in other field of science, and even in technology around $800 \mathrm{BC}$ in Andalusia, Ibn Firnas designed flying tool just like with what Roger Beacon (1292 AD) created. Recently, it's introduced by Leonardo Da Vinci (1519 AD). ${ }^{18}$

A simple question is how come? An attention by Syamsuddin Arif whose article Sciences in the World of Islam: Historic-Sociologic Study classified the factors of science development in the world of Islam. First is, firm adherence to, understanding and practicing of, true Islamic faith and teachings. Second is religion motivation and third is the factor of politic social; political unity stability, peace and order, because of faith and in spite of ethnic as well as cultural diversity. Science seeker and scholar freely traveled and felt save to go to center of education and knowledge from Seville to Baghdad, Samarkand to Medina, Isfahan to Cairo or even from Yaman to Damascus as stated in SeekKnowledge: Thought and Travel in the House of Islam by Richmond. Also Ibn Jubayr (1217 AD) and Ibn Batutah (1377 AD) who adventured all over the world of Islam. ${ }^{19}$

${ }^{17}$ Syamsuddin Arif, “Sains di Dunia Islam: Telaah Historis-Sosiologis,” p. 88.

${ }^{18}$ Syamsuddin Arif, "Sains di Dunia Islam: Telaah Historis-Sosiologis," p. 89.

${ }^{19}$ Syamsuddin Arif, “Sains di Dunia Islam: Telaah Historis-Sosiologis," p. 90. 
The economic factor has an important role in self developing and reaching the goal, such as Imam ad-Dhahabi (1348 AD) and Ibn Hazm (1064 AD). George Makdis in his book The Rise of Colleges: Institutions of Learning in Islam and the West stated that university and high school like Nizamiyyah, Aziziyyah, Mustansirriyyah where guaranteed the living cost and prosperity of teacher staff and students, so that they can focus on their field and careers to produce the scientific works. ${ }^{20}$

The important of patronage as a support and protection became an important factor. A sociology expert, Toby E. Huff in his book Rise of Early Modern Science: Islam, China and the West said, "The considerable freedom and resources that certain outstanding philosophers and mathematician had to pursue their studies. However, was always contingent upon the official protection as local rulers. As Willy Hartner pointed out in the case of more than a dozen notable figures such as al-Biruni, Ibn Sina, Abu al-Wafa, Ibn Yunas, and Ibn al-Haytami, royal patronage was a major element in their careers once that direct ring of protection and approval was withdrawn, scholars immersed in philosophy and the foreign sciences could easily fall into dispute, as happened to Averroes, despite the fact that he had served as the chief Qadi of Cordoba for years. $^{21}$

What described above were concrete factors influencing the development of science in the history of Islamic civilization on the facts of history written in the classic literature. The problem is how we can set an example for, and the rest is question: is it buried as a memory or in memorial? Or we, especially Indonesian Moslems will set an example for or learn from the history to reach the glory?

\section{Islamic Education as a Midwife for the Birth of Modern Sciences}

M. Natsir Arsyad in his book Ilmuwan Muslim Sepanjang Sejarah also A.J. Arberry Moslem Saints and Mystics stated that historically Islamic civilization

\footnotetext{
${ }^{20}$ Syamsuddin Arif, "Sains di Dunia Islam: Telaah Historis-Sosiologis," p. 90.

${ }^{21}$ Toby. E. Huff, The Rise of Early Modern Science: Islam, China and the West (Cambridge: Cambridge University Press, 1993), p. 69.
} 
had risen the thousands of world caliber scholars with their original discoveries in the field of mathematic, physics, chemistry, astronomy, botany, and medical. According to Hasan Basri in the book Menyingkap Zaman keemasan Islam also Charles Michael Stanton in Higher Learning in Islam: The Classical Period, 700$1300 A D$., seem like agree with the information mentioned above, that was happen in the Islamic golden era since century IX to XII. Many education institutions had important role in developing this intellectual world were kuttāb, masjid - khan, madrasah, dār al-Qur'ān, bayt al-hikmah and dar alhadith, besides libraries and observatories and mystical institution such as Ribath, Zawiyah, and Khanqah. A question perhaps appears to search an answer is: is it apologetic to say that Islam is midwife for the birth of modern sciences? ${ }^{22}$

The institutions of Islamic education in this industrial era right now also ought to have an important role in developing intellectual world, especially in the Moslem countries. So that, it is necessary for all pupils to familiar with the modern sciences to study, predict and reconstruct the future civilization, as what had been done by some Moslem scholars. Malek Bennabi, for instance, a Moslem scholar of Algeria, in Membangun Dunia Baru Islam he has interestedly analyzed the history and future of Moslem community. It was unique as his developing theories were based on the formulas of mathematics and physics more because his education background was exacts sciences. But, he might feel not necessary to present the global solution for Moslem community's decline, to revive and reconstruct their future civilization. He preferred to describe the casuistic problems of some Moslem countries (Egypt, Pakistan, and Indonesia) then compared them with the historical experience of the Moslem community of Algeria. ${ }^{23}$

The other Moslem scholars gave the formula of global solution. To reconstruct the Islamic civilization, in the book Rekayasa Masa Depan Peradaban Muslim, Ziauddin Sardar said that it must by applying the "systemview" in the cultural context towards the Moslem countries in the last and nowadays period. It must explicitly illustrate the possible alternative to develop

\footnotetext{
${ }^{22} \mathrm{Abu}$ Darda', "Islamic Education for the Future”, p. 45.

${ }^{23} \mathrm{Abu}$ Darda', "Islamic Education for the Future”, p. 45-46.
} 
the methodology and redirect it to the Islamic way. Meanwhile, according to Kuntowijoyo, a Moslem historian of Indonesia as it is stated in his book Pradigma Islam: Interpretasi untuk Aksi, to reconstruct Islamic civilization, the Moslems should re-actualize the values of Islam. In this case, he offered the five reinterpretations as follows: (1) To develop the social structural interpretations in understanding the certain norm of al-Quran surpasses the individual interpretation. (2) To change the subjective reasoning method by the objective resoning method. (3) To create the normative interpretation on the verses of alQuran becomes the scientific theoritical frame. (4) To change the a-historical understanding to the historical understanding. (5) To reformulate the general revelation formulation to spesific and empiric formulation. ${ }^{24}$

The formulas above: the specific and global solution on the decline of Moslem community indicate that expectation to Islamic industrial civilization is optimistic and rational expectation means that Islamic education has to over come its challenges, externally and internally. ${ }^{25}$ For more, one important thing to say is an urgency of being realized that Moslems can not live in the pride of golden memory only then make that golden era such as an apology. Recognizing the sociology and history of the origin of knowledge-Greek as a source-will show the consciousness to change the a-historical understanding. In fact, Islamic education had an important role in developing the modern sciences but in the change of historical understanding it is not true that Islam is midwife for modern sciences birth.

\section{E. In need of the Modern Sciences}

The fact of some Moslem scholars resist the modern sciences, the science where the formulas of industrial Islamic civilization reconstruction mentioned above could not avoid the methodology of natural or social sciences that come from the West. According to Kuntowijoyo, the process of borrowing and giving is experienced by the whole civilization in their interactions along the history. The Moslem community must not reconstruct their civilization from the zero. They must not dichotomize it for it means they are exclusive. Islam according to

\footnotetext{
${ }^{24} \mathrm{Abu}$ Darda', "Islamic Education for the Future”, p. 46.

${ }^{25} \mathrm{Abu}$ Darda', "Islamic Education for the Future”, p. 46.
} 
him is "an open paradigm". It must inherit the historical tradition of civilization of all over the world. ${ }^{26}$

This resistance to modern sciences really shows an expression of the frigid of theology. It is the wrong attitude and should not happen. Perves Hoodbhoy in the book Ikhtiar Menegakkan Rasionalitas: Antara Sains dan Ortodoksi Islam concluded the sad situation of many Moslem countries was caused by this attitude. ${ }^{27}$ One of factors to determine the success of Moslem community in facing the rapid changes is the progression of science and technology. The frigid system of theology should be reformed. Bassam Tibbi in Krisis Peradaban Islam Modern: Sebuah Kultur Pra-Industri dalam Era ilmu Pengetahuan dan Teknologi is not pessimist, this sad situation will be going away because the frigid theology and jurisprudence of the pre-industrial culture are in the process of being left and changed. ${ }^{28}$

However, the modern sciences should be evaluated before being applied to solve the problems of Moslem community. This is the attitude to modern sciences and technology. Therefore, The World Conference on Moslem Education in Mecca in the year 1977 had several main ideas as follows: (1) The rapid social change needs mastery on the science and technology in all aspects of life. (2) Madrasah as the institution of education possessed by Moslem community does not teach except the religious traditional sciences. (3) The public school that teaches the modern sciences and various aspects of life is proved only adopting the west $100 \%$. (4) Those modern sciences involve the western methodology which is full of western methodology that is considered destroying the religious and humanity values. (5) The adopted modern sciences by Moslem community bring them to the western model of problem solving in social, political, and economic without paying attention to the values of religion and humanity. (6) The solution toward those problems is to produce the concept of modern sciences and technology by Islamic methodology. Then it is printed and published as handbook. ${ }^{29}$

\footnotetext{
${ }^{26}$ Syed Hossen Nasr, Menjelajah Dunia Modern: Bimbingan untuk Kaum Muda Muslim, (Bandung: Mizan, 1995), p. 290.

${ }^{27}$ Abu Darda', "Islamic Education for the Future”, p. 47.

${ }^{28}$ Abu Darda', "Islamic Education for the Future", p. 48.

${ }^{29}$ Syed Sajjad Husain and Syed Ali Ashraf, Crisis in Muslim Education, (Jeddah: King Abdul Aziz University, 1980), p. 3.
} 
The second seminar on islamization of knowledge is held also in Islamabad, Pakistan in the year $1982^{30}$ and other places countries. By those seminars, the Moslem communities are expected to have the right attitude towards modern sciences and technology with consistently keeping the world-view of tawhid. ${ }^{31}$

Whilst, the Idea on how madrasah teaches only the religious traditional science shows that this phenomenon really still could be seen nowadays. In this case, what Moslems to do is to be opening minded and learn how to be more adult in facing the developing sciences and technology that become realities in front of the face. In other words, avoiding the modern sciences and technology means to deny the existence of progressing human to be perfect. And accepting them as a friend of life does not mean to decline the value of human or to reduce religious values.

\section{F. Conclusion}

Modern science is the result of education. It indicates the civilization where educated people are able to have a better life which is compatible with the values of religion. A religion that becomes foot step to walk and heart to talk in step of the change of life should be more than just becomes a background of the study or religious educational institution but it can be understood as an understanding religion as well with no frigid theology understanding.

Toward modern science, Moslem's attitude of today is fallen into pieces: absolutely resist and refuse, and take it for granted. Both of them are really extreme attitude. Education as a root of civilization has an important role in establishing the positive attitude toward science development. Islamic education is expected to be able to assure Moslem that science and its development is compatible with the Islamic values. So that Moslem can feel free to face the modern sciences by appreciating and applying them properly.

One important thing is by learning from the golden history of Islamic education, Indonesian Islamic education should be reconstructed in to modern system. Perhaps the knowledge is classic as inheritance but the way in transforming should be conducted in modern with no any objection of modern

\footnotetext{
${ }^{30}$ N.A. Baloch (editor), "Knowledge For What", being the proceedings and papers of the seminar on Islamization of Knowledge, National Hijra Council, Islamabad, Pakistan, 1986.

${ }^{31}$ Abu Darda', "Islamic Education for the Future”, p. 48.
} 
science. As everything is changing including the educational institution, Islamic education will be left behind again if Moslems are still afraid of being open mind in understanding the result of civilization, science.[w] 


\section{BIBLIOGRAPHY}

Arif, Syamsuddin, "Sciences in the World of Islam: Historic-Sociologic Study", Jurnal Islamia, Jakarta, 2005.

Azra, Azyumardi, "Desentralisasi Pendidikan dan Otonomi Daerah" (Decentralization of Education and Regional Autonomy"), Journal AtTa'dib. Vol. 2, No. 1, 2015.

Baloch, N.A. (editor), "Knowledge For What", being the Proceedings and Papers of the Seminar on Islamization of Knowledge Islamabad, Pakistan: National Hijra Council, 1986.

Darda', Abu, "Islamic Education for the Future". Jurnal Kependidikan Islam AtTa'dib, Gontor, 2005.

al-Fendi, M.H., "Toward Islamic Curricula", in M.H. al-Fendi \& N.A. Baloch (eds.), Curriculum and Teacher Education, Jedah: King Abdul Aziz University/ London: Hodder and Stounghton., 1980.

http://web.nut.edu/mitmsa/www/NewSite/libstuff/nasr/nasrspeech1.html, accessed on September 12th, 2015.

Husain, Syed Sajjad and Syed Ali Ashraf, Crisis in Moslem Education, Jeddah: King Abdul Aziz University, 1980.

Maimun, Agus, Intro to Thought of Islamic Education in Indonesia, Malang: Research and Education Development, 2008.

Nasr, Seyyed Hossen, Menjelajah Dunia Modern: Bimbingan Untuk Kaum Muda Muslim (Exploring Modern World: Guidance for Young Moslems), Bandung: Mizan, 1995.

Toby. E. Huff, The Rise of Early Modern Science: Islam, China and the West Cambridge: Cambridge University Press, 1993.

Zuhairini, Sejarah Pendidikan Islam (History of Islamic Education), Jakarta: Ditbinperta, 1986. 